\title{
Respon Tanaman Kentang Hitam (Solenostemon Rotundifolius) pada Berbagai Jumlah dan Frekuensi Pemberian Air
}

\author{
Primarini Dayu Ardani ${ }^{1)}$, Nur Edy Suminarti ${ }^{2)}$, Agung Nugroho ${ }^{3)}$ \\ 1),2), 3) Fakultas Pertanian Universitas Brawijaya \\ Alamat korespondensi: ${ }^{1)}$ dprimada2013@gmail.com
}

\begin{abstract}
ABSTRAK
Kentang hitam (Solenostemon rotundifolius) adalah bahan pangan yang cukup lama dikenal di Indonesia, akan tetapi tingkat kebutuhan air yang terkait dengan tingkat ketersediaan serta pendistribusiannya secara merata pada seluruh fase pertumbuhan tanaman masih belum diketahui. Penelitian untuk mempelajari dan memperoleh informasi tentang jumlah dan frekuensi pemberian air yang tepat untuk pertumbuhan dan hasil tanaman kentang hitam telah dilakukan di Greenhouse BLK Wonojati, Malang pada November 2016-Maret 2017. Rancangan yang digunakan adalah Rancangan Petak Terbagi, frekuensi pemberian air diletakkan sebagai petak utama, terdiri dari tiga macam: sehari sekali, dua hari sekali dan tiga hari sekali. Jumlah pemberian air sebagai anak petak yang terdiri dari empat level: 300, 600, 900 dan $1200 \mathrm{~mm} \mathrm{musim}^{-1}$. Pengumpulan data dilakukan secara destruktif meliputi komponen pertumbuhan dan hasil. Hasil penelitian menunjukkan bahwa frekuensi pemberian air sehari sekali pada pemberian air sebanyak $900 \mathrm{~mm}$ musim $^{-1}$ menunjukkan bobot kering total tanaman yang lebih tinggi, jumlah daun dan bobot kering daun yang lebih tinggi. Kedua perlakuan tidak memberikan pengaruh nyata pada semua parameter panen.
\end{abstract}

Kata kunci: Jumlah air, frekuensi penyiraman, pemberian air, Solenostemon rotundifolius

\section{ABSTRACT}

Black potato (Solenostemon rotundifolius) is well known in Indonesia for long time; however, the water needs for the plant growth is still remain unknown. The availability and distribution among plants' life in each growth phase has become a concern, equally. The research aimed to study and provide information about the optimum water requirement in quantity and frequency for the growth and yield of black potato. This study has been done in Greenhouse of BLK Wonojati, Malang from Nov 2016-March 2017. The split plot design used with three different watering frequencies as main plot: once a day, once for two days and once for three days and four levels of water amount as the subplot: $300,600,900$ and $1200 \mathrm{~mm}$ season $^{-1}$. Data were collected destructively consisting growth and yield parameters. Results showed that watering $900 \mathrm{~mm}$ season $^{-1}$ provisioning once a day gave higher total dry weight and provisioning once a day in amount $900 \mathrm{~mm}^{-1}$ season $^{-1}$ gave higher amount of leaves and leaf dry weight. Both treatments gave no tangible result to all harvest parameters.

Keywords: Water amount, watering frequency, irrigation, Solenostemon rotundifolius

\section{PENDAHULUAN}

Kondisi iklim yang semakin sulit diprediksi dan semakin berkembangnya jumlah penduduk dunia menyebabkan sulitnya terjadi keseimbangan antara ketersediaan bahan pangan dan permintaannya. Krisis pangan tersebut memicu berbagai negara untuk mulai mempertimbangkan berbagai bahan pangan alternatif, terutama bahan pangan berbasis karbohidrat. Setelah banyak varian baru dari tanaman dari famili Graminae dan Fabaceael Leguminoceae diperkenalkan, sumber karbohidrat yang berasal dari tanaman umbiumbian mulai diminati. Salah satunya adalah tanaman kentang hitam (Solenostemon rotundifolius (Poir) J.K Morton) yang termasuk dalam famili Lamiaceae [1]. Umbi kentang hitam sebenarnya sudah cukup lama dikenal masyarakat Indonesia, walaupun masih belum sepopuler bahan pangan umbi-umbian lainnya, misalnya ubi jalar, singkong, kentang dan talas. Umbi mentah kentang hitam per $100 \mathrm{~g}$ mengandung $76 \%$ air, $21 \%$ karbohidrat, $1,4 \%$ protein, $0,7 \%$ serat, $0,2 \%$ lemak serta $0,1 \%$ abu dan juga kaya vitamin dan mineral ${ }^{2}$. Selain 
kandungan tersebut di atas, umbi kentang hitam juga memiliki kandungan antioksidan asam ursolik dan asam oleanolik yang cukup tinggi, sehingga mampu mereduksi dan menghambat proliferasi sel kanker [3].

Tanaman kentang hitam tumbuh subur di negara-negara beriklim tropis dan sub-tropis. Di Indonesia, tanaman ini umumnya ditanam pada bulan basah yaitu pada awal musim penghujan, sehingga hanya tersedia pada musim tertentu. Petani jarang sekali menanam tanaman kentang hitam pada musim kemarau, karena rendahnya tingkat ketersediaan air tanah. Walaupun Priya dan Abuselvi [4] menyatakan bahwa tanaman kentang hitam cukup toleran terhadap kekeringan, namun demikian sejauh ini belum ada informasi yang menyebutkan tentang tingkat kebutuhan air pada tanaman kentang hitam, karena sebagian besar penelitian hanya difokuskan pada perbanyakan bahan tanam dan varietas melalui pemuliaan tanaman ${ }^{5,6,1}$. Padahal kelangsungan hidup tanaman tidak hanya ditentukan oleh bahan tanam saja, tetapi air juga merupakan senyawa yang sangat penting. Hampir 90\% tubuh tanaman terdiri dari air. Air, selain berfungsi sebagai media pengangkut dan pelarut, air juga berperan dalam proses membuka dan menutupnya stomata. Apabila air tersedia cukup, maka stomata akan membuka sebagai akibat meningkatnya turgiditas sel sehingga kegiatan fotosintesa akan terjadi. Akan tetapi, ketika tanaman mengalami kekurangan air, maka stomata akan menutup. Penutupan stomata ini merupakan cara adaptasi tanaman ketika tanaman mengalami kekurangan air. Mekanisme ini bertujuan untuk menekan lebih banyaknya air yang hilang akibat proses evapotranspirasi. Tetapi di sisi lain, penutupan stomata tersebut merupakan suatu kegiatan yang merugikan tanaman karena tidak dapat melangsungkan kegiatan fotosintesa.

Sehubungan dengan pentingnya peranan air ini, maka informasi tentang kebutuhan air optimum pada tanaman kentang hitam sangat diperlukan. Namun demikian, hal lain yang perlu diperhatikan dalam kaitannya dengan kebutuhan air ini adalah tingkat ketersediaannya. Air yang terdistribusikan secara merata sepanjang fase pertumbuhan-nya adalah lebih baik daripada yang terakumulasi dalam salah satu fase, karena tingkat kebutuhan air sangat ditentukan oleh fase pertumbuhan tanaman. Kebutuhan air pada fase vegetatif awal, akan sangat berbeda dengan kebutuhan air pada fase vegetatif puncak. Oleh karena itu, untuk mengetahui seberapa besar pengaruh dari tingkat ketersediaan air tersebut, maka uji frekuensi pemberian air perlu dilakukan. Diharapkan melalui penelitian ini akan didapatkan formulasi yang tepat tentang kebutuhan air dan frekuensi pemberian air yang tepat pada tanaman kentang hitam, sehingga hasilnya dapat ditingkatkan.

\section{METODE PENELITIAN}

Penelitian telah dilakukan pada bulan November 2015 - Maret 2016 di Green house Balai Latihan Kerja Pertanian dan Pengembangan Tenaga Kerja Luar Negeri (BLKPPTKLN) Wonojati, Kecamatan Singosari, Kabupaten Malang. Penelitian menggunakan Rancangan Petak Terbagi (RPT), dengan frekuensi pemberian air sebagai petak utama, terdiri dari tiga macam, yaitu: setiap hari, pemberian air dua hari sekali dan pemberian air tiga hari sekali. Jumlah pemberian air sebagai anak petak, terdiri dari empat takaran, yaitu: 300 , 600, 900 dan $1200 \mathrm{~mm} \mathrm{musim}^{-1}$. Setiap perlakuan diulang tiga kali, sehingga diperoleh 36 kombinasi perlakuan.

Bahan yang digunakan berupa stek pucuk yang berasal dari umbi kentang hitam varietas lokal yang dipotong dengan panjang sekitar 10 $\mathrm{cm}$, tanah alfisol, dan air yang digunakan sebagai perlakuan, pupuk N $30 \mathrm{~kg} \mathrm{ha}^{-1}$ dalam bentuk Urea $(45 \% \mathrm{~N})$ sebanyak $66,67 \mathrm{~kg} \mathrm{ha}^{-1}$, pupuk $\mathrm{P}$ $60 \mathrm{~kg}$ P2O5 ha ${ }^{-1}$ dalam bentuk TSP (46\% P2O5) sebanyak 130,44 $\mathrm{kg} \mathrm{ha}^{-1}$ dan pupuk K $50 \mathrm{~kg} \mathrm{K2O}$ ha $^{-1}$ dalam bentuk $\mathrm{KCl}(60 \% \mathrm{~K} 2 \mathrm{O})$ sebanyak $83,33 \mathrm{~kg} \mathrm{ha}^{-1}$ yang diaplikasikan tiga kali, yaitu pada 7 hari sebelum penanaman bibit, 20 HST dan 100 HST, fungisida Furadan dengan dosis 1 $\mathrm{mL} \mathrm{L}^{-1}$ yang diaplikasikan pada stek dengan cara direndam dalam larutan selama 10 menit sebelum ditanam serta insektisida Decis 25EC dengan dosis $0,5 \mathrm{~mL} \mathrm{~L}^{-1}$ untuk mengatasi hama belalang, yang diaplikasikan setiap dua minggu sekali dengan cara disemprotkan pada permukaan tajuk tanaman. Alat yang digunakan dalam penelitian ini adalah polibag dengan kapasitas $5 \mathrm{~kg}$ dengan diameter $17 \mathrm{~cm}$, gelas plastik yang sudah diberi label jumlah air per fase per musim, timbangan analitik, penggaris, Leaf Area Meter, timbangan ukur, oven, kantung kertas serta alat tulis.

Air diberikan sesuai dengan perlakuan yaitu 300, 600, 900 dan $1200 \mathrm{~mm}_{\text {musim }}{ }^{-1}$. Jumlah pemberian air yang dibutuhkan pada setiap fase pertumbuhan disajikan pada Tabel 1. Pemberian air pada tiap fase pertumbuhan tersebut 
dilakukan dengan interval sesuai dengan diberikan setiap hari, dua hari sekali dan tiga hari perlakuan frekuensi pemberian air, yaitu sekali.

Tabel 1. Jumlah air yang diberikan tiap fase pertumbuhan tanaman kentang hitam per perlakuan per hari per tanaman

\begin{tabular}{ccccccc}
\hline \multirow{2}{*}{ Perlakuan } & \multicolumn{6}{c}{ Jumlah air (cc/ hari/ tanaman) } \\
\cline { 2 - 7 } & $\mathbf{1 - 1 2}$ & $\mathbf{1 2 - 2 6}$ & $\mathbf{2 7 - 6 8}$ & $\mathbf{6 9 - 9 6}$ & $\mathbf{9 7 - 1 1 7}$ & $\mathbf{1 1 8 - 1 3 1}$ \\
\hline $300 \mathrm{~mm}$ & 48,62 & 53,18 & 33,31 & 58,61 & 64,09 & 73,99 \\
$600 \mathrm{~mm}$ & 97,23 & 110,35 & 66,60 & 115,79 & 128,19 & 147,97 \\
$900 \mathrm{~mm}$ & 145,85 & 165,53 & 99,90 & 173,68 & 192,28 & 221,96 \\
$1200 \mathrm{~mm}$ & 194,47 & 220,71 & 133,20 & 231,58 & 256,38 & 295,95 \\
\hline
\end{tabular}

Pengumpulan data dilakukan secara destruktif dengan mengambil tiga sampel untuk setiap kombinasi perlakuan pada setiap pengamatan. Parameter yang diamati meliputi:

A. Komponen pertumbuhan, yaitu:

1. Jumlah daun per tanaman, dihitung semua daun yang tumbuh dan telah membuka sempurna dan masih berwarna hijau.

2. Luas daun $\left(\mathrm{cm}^{2}\right)$, diukur dengan menggunakan Leaf Area Meter tipe CL-203 untuk semua daun yang telah membuka sempurna dan masih berwarna hijau

3. Bobot kering daun $\left(\mathrm{g} \tan ^{-1}\right)$, ditimbang seluruh daun yang terbentuk dengan menggunakan timbangan analitik setelah dioven pada suhu $81^{\circ} \mathrm{C}$ hingga diperoleh bobot yang konstan.

4. Bobot kering total tanaman $\left(\mathrm{g} \mathrm{tan}^{-1}\right)$, ditimbang seluruh bagian tanaman yang terbentuk selain umbi dengan menggunakan timbangan analitik setelah dioven pada suhu $81^{\circ} \mathrm{C}$ hingga diperoleh bobot yang konstan

5. Harga satuan daun (HSD), dihitung dengan menggunakan rumus [9]:

6.

$$
H S D=\frac{2\left(W_{2}-W_{1}\right)}{\left(L D_{1}+L D_{2}\right)\left(T_{2}-T_{1}\right)}\left(\mathrm{mg} \mathrm{cm}^{-2} \text { hari' }{ }^{-1}\right)
$$

Keterangan: W1 =bobot kering total tanaman pada $\mathrm{T} 1$; LD1 = luas daun pada $\mathrm{T} 1 ; \mathrm{W} 2$ = bobot kering total tanaman pada T2; LD2 = luas daun pada T2; T1 $=$ waktu pengamatan ke-1; T2 = waktu pengamatan ke-2

7. Laju Pertumbuhan Relatif (LPR), dihitung dengan menggunakan rumus [7]:

$L P R=\frac{\operatorname{Ln} W_{2}-\operatorname{Ln} W_{1}}{T_{2}-T_{1}}\left(g^{-1}\right.$ harr $\left.^{-1}\right)$

Keterangan: W2 = bobot kering total tanaman pada $\mathrm{T} 2$; $\mathrm{T} 1$ = waktu pengamatan ke-1; $\mathrm{W} 1$ = bobot kering total tanaman pada T1 T2 = waktu pengamatan ke- 2

8. Efisiensi Penggunaan Air (EPA) yang dihitung menggunakan rumus [7]:

Efisiensi Penggunaan Air $=\frac{\text { Bobot kering total tanaman }}{\text { Jumlah air yang diberkan }}(\mathrm{g} \mathrm{kg}$ air')

B. Panen, dilakukan pada umur 131 hst atau pada saat $90 \%$ daun sudah menguning. Paramenter yang diamati yaitu:

1. Jumlah umbi per tanaman, dihitung semua umbi yang terbentuk pada setiap tanaman

2. Bobot basah umbi per tanaman $\left(\mathrm{g}^{-1} \tan ^{-1}\right)$, ditimbang seluruh umbi yang terbentuk pada setiap tanaman dengan menggunakan timbangan analitik.

3. Bobot kering umbi per tanaman $\left(\mathrm{g}^{-1} \tan ^{-1}\right)$, ditimbang seluruh umbi yang terbentuk pada setiap tanaman dengan menggunakan timbangan analitik setelah dioven pada suhu $81^{\circ} \mathrm{C}$ hingga diperoleh bobot yang konstan.

Data yang diperoleh dari hasil pengamatan dianalisis dengan menggunakan analisis ragam (uji F) pada taraf 5\%. Apabila terjadi interaksi dan pengaruh nyata dari perlakuan maka dilanjutkan dengan uji Beda Nyata Terkecil (BNT) pada taraf 5\% untuk mengetahui perbedaan di antara perlakuan. 


\section{HASIL DAN PEMBAHASAN}

Interaksi nyata terjadi pada parameter jumlah daun dan Efisiensi Penggunaan Air (EPA), sedangkan pengaruh nyata terjadi pada parameter luas daun, bobot kering daun dan bobot kering total tanaman.. Jumlah dan frekuensi pemberian air tidak berpengaruh nyata pada seluruh komponen panen yang diamati, Harga Satuan
Daun (HSD) dan Laju Pertumbuhan Relatif (LPR).

\section{Komponen pertumbuhan}

\section{Jumlah daun}

Rerata jumlah daun per tanaman akibat terjadinya interaksi nyata antara jumlah dan frekuensi pemberian air disajikan pada Tabel 2 .

Tabel 2. Rerata jumlah daun per tanaman akibat interaksi nyata antara jumlah dan frekuensi pemberian air pada umur $81 \mathrm{hst}$

\begin{tabular}{lrrrr}
\hline Frekuensi & \multicolumn{4}{c}{ Jumlah Pemberian Air $\mathbf{( m m ~ m u s i m}^{-\mathbf{1}} \mathbf{)}$} \\
Penyiraman & 300 & 600 & 900 & 1200 \\
\hline Sehari sekali & $65,33 \mathrm{a}$ & $114,00 \mathrm{a}$ & $241,00 \mathrm{~b}$ & $401,00 \mathrm{c}$ \\
& $\mathrm{A}$ & $\mathrm{A}$ & $\mathrm{A}$ & $\mathrm{B}$ \\
Dua hari sekali & $55,00 \mathrm{a}$ & $144,67 \mathrm{a}$ & $260,67 \mathrm{~b}$ & $358,33 \mathrm{~b}$ \\
& $\mathrm{~A}$ & $\mathrm{~A}$ & $\mathrm{~A}$ & $\mathrm{~B}$ \\
Tiga hari sekali & $59,00 \mathrm{a}$ & $124,00 \mathrm{a}$ & $311,00 \mathrm{~b}$ & $247,00 \mathrm{~b}$ \\
& $\mathrm{~A}$ & $\mathrm{~A}$ & $\mathrm{~A}$ & $\mathrm{~A}$ \\
\hline
\end{tabular}

BNT 5\%

102,02

Keterangan:Bilangan yang didampingi oleh huruf kecil yang sama pada baris yang sama atau huruf besar yang sama pada kolom yang sama menunjukkan tidak berbeda nyata pada uji BNT taraf $5 \%$, hst $=$ hari setelah tanam, BNT $=$ Beda Nyata Terkecil

Pada frekuensi pemberian air sehari sekali, jumlah daun paling banyak didapatkan pada pemberian air $1200 \mathrm{~mm} \mathrm{musim}^{-1}$. Pengurangan jumlah pemberian air dari $1200 \mathrm{~mm} \mathrm{musim}^{-1}$

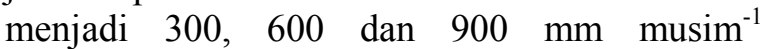
menyebabkan berkurangnya jumlah daun masing-masing sebesar $83,71 \%, 71,57 \%$ dan $39,90 \%$. Jumlah daun juga mengalami penurunan sebesar $72,89 \%$ dan $52,70 \%$ ketika pemberian air dikurangi dari $900 \mathrm{~mm} \mathrm{musim}^{-1}$ menjadi 300 dan $600 \mathrm{~mm} \mathrm{musim}^{-1}$. Jumlah daun menunjukkan hasil yang tidak berbeda nyata pada pemberian air 300 dan $600 \mathrm{~mm} \mathrm{musim}^{-1}$. Hasil penelitian seperti ini juga terjadi pada perlakuan frekuensi penyiraman dua hari sekali. Pada frekuensi penyiraman tiga hari sekali, jumlah daun terbanyak didapatkan pada pemberian air 900 $\mathrm{mm}$ musim $^{-1}$ dan menyebabkan berkurangnya jumlah daun ketika jumlah pemberian air diturunkan dari $900 \mathrm{~mm}$ musim $^{-1}$ menjadi 600 hingga $300 \mathrm{~mm} \mathrm{musim}^{-1}$. Hal ini juga terjadi ketika jumlah pemberian air ditingkatkan dari 900 menjadi $1200 \mathrm{~mm}^{\text {musim }}{ }^{-1}$.

Jumlah daun menunjukkan hasil yang tidak berbeda nyata pada berbagai jumlah pemberian air $\left(300,600\right.$ dan $900 \mathrm{~mm} \mathrm{musim}^{-1}$ ) pada berbagai frekuensi pemberian. Akan tetapi, pada pemberian air sebanyak $1200 \mathrm{~mm} \mathrm{musim}^{-1}$, frekuensi pemberian air sehari dan dua hari sekali menghasilkan jumlah daun yang lebih banyak dibandingkan frekuensi pemberian air tiga hari sekali.

\section{Luas daun}

Rerata luas daun akibat terjadinya interaksi nyata antara jumlah dan frekuensi pemberian air pada umur 27 hst disajikan pada Tabel 3

Tabel 3. Rerata luas daun $\left(\mathrm{cm}^{2} \tan ^{-1}\right)$ akibat interaksi nyata antara jumlah dan frekuensi pemberian air pada umur $27 \mathrm{hst}$

\begin{tabular}{lrrrr}
\hline Frekuensi & \multicolumn{4}{c}{ Jumlah air $\left(\mathbf{m m}\right.$ musim $\left.^{-1}\right)$} \\
\cline { 2 - 5 } Pemberian Air & \multicolumn{1}{c}{300} & 600 & 900 & 1200 \\
\hline Sehari sekali & $353,42 \mathrm{ab}$ & $204,59 \mathrm{a}$ & $466,29 \mathrm{ab}$ & $713,06 \mathrm{~b}$ \\
& $\mathrm{~A}$ & $\mathrm{~A}$ & $\mathrm{~A}$ & $\mathrm{~B}$ \\
Dua hari sekali & $376,15 \mathrm{a}$ & $520,32 \mathrm{a}$ & $405,94 \mathrm{a}$ & $557,59 \mathrm{a}$ \\
& $\mathrm{A}$ & $\mathrm{B}$ & $\mathrm{A}$ & $\mathrm{AB}$ \\
\hline
\end{tabular}




\begin{tabular}{rrrrr} 
Tiga hari sekali & $351,21 \mathrm{ab}$ & $480,92 \mathrm{ab}$ & $599,68 \mathrm{~b}$ & $282,10 \mathrm{a}$ \\
& $\mathrm{A}$ & $\mathrm{AB}$ & $\mathrm{A}$ & $\mathrm{A}$ \\
\hline
\end{tabular}

BNT 5\%

310,59

Keterangan:Bilangan yang didampingi oleh huruf kecil yang sama pada baris yang sama atau huruf besar yang sama pada kolom yang sama menunjukkan tidak berbeda nyata pada uji BNT taraf 5\%, hst $=$ hari setelah tanam, BNT $=$ Beda Nyata Terkecil

Pada frekuensi pemberian air sehari sekali, luas daun yang tertinggi didapatkan pada pemberian air $1200 \mathrm{~mm} \mathrm{musim}^{-1}$. Peningkatan jumlah pemberian air dari $1200 \mathrm{~mm}$ musim-1 menjadi 300 hingga $600 \mathrm{~mm}$ musim $^{-1}$ meningkatkan luas daun masing-masing sebesar $50,44 \%$ dan $71,31 \%$. Luas daun tidak berbeda nyata pada pemberian air 900 dan $1200 \mathrm{~mm}$ musim $^{-1}$. Pada frekuensi pemberian air dua hari sekali, luas daun yang dihasilkan tidak berbeda nyata pada semua level jumlah pemberian air. Sedangkan pada frekuensi tiga hari sekali, luas daun mengalami peningkatan $52,96 \%$ ketika jumlah air diturunkan dari $1200 \mathrm{~mm} \mathrm{musim}^{-1}$ menjadi $900 \mathrm{~mm} \mathrm{musim}^{-1}$. Adapun, luas daun yang didapatkan pemberian air sebanyak 300 , 600 dan $1200 \mathrm{~mm}^{2}$ musim ${ }^{-1}$ tidak berbeda nyata, sedangkan di sisi lain luas daun juga tidak berbeda nyata pada pemberian air sebanyak 300 , 600 dan $900 \mathrm{~mm}^{\text {musim }}{ }^{-1}$.

Apabila dilihat dari perlakuan jumlah air terhadap frekuensinya, didapatkan bahwa luas daun pada pemberian air 300 dan $900 \mathrm{~mm}$ musim $^{-1}$ memperlihatkan hasil yang tidak berbeda nyata pada semua level frekuensi pemberian. Sedangkan pada pemberian air 600 $\mathrm{mm}$ musim $^{-1}$, frekuensi pemberian air sehari sekali dan tiga hari sekali menunjukkan luas daun yang tidak berbeda nyata. Penambahan frekuensi pemberian air dari sehari sekali menjadi dua hari sekali meningkatan luas daun sebesar $60,68 \%$, walaupun luas daun pada tanaman yang diberi air dua hari sekali dan tiga hari sekali menunjukkan hasil yang tidak berbeda nyata. Peningkatan frekuensi pemberian air dari sehari sekali menjadi tiga hari sekali menurunkan luas daun sebesar $60,44 \%$ pada pemberian air sebanyak $1200 \mathrm{~mm} \mathrm{musim}^{-1}$. Pemberian air dengan frekuensi sehari sekali dan dua hari sekali memperlihatkan hasil luas daun yang tidak berbeda nyata dan di sisi lain, frekuensi pemberian air dua hari sekali dan tiga hari sekali juga memberikan luas daun yang tidak berbeda nyata.

\section{Bobot kering daun}

Rerata bobot kering daun akibat terjadinya interaksi nyata antara jumlah dan frekuensi pemberian air pada umur 27 hst disajikan pada Tabel 4

Tabel 4. Rerata bobot kering daun $\left(\mathrm{g} \mathrm{tan}^{-1}\right)$ akibat interaksi nyata antara jumlah dan fre-kuensi pemberian air pada umur $27 \mathrm{hst}$

\begin{tabular}{|c|c|c|c|c|}
\hline \multirow{2}{*}{$\begin{array}{c}\text { Frekuensi } \\
\text { Pemberian Air }\end{array}$} & \multicolumn{4}{|c|}{ Jumlah air (mm musim $\left.{ }^{-1}\right)$} \\
\hline & 300 & 600 & 900 & 1200 \\
\hline Sehari sekali & $0,72 \mathrm{a}$ & $0,56 \mathrm{a}$ & $0,86 \mathrm{a}$ & $1,49 \mathrm{~b}$ \\
\hline & A & $\mathrm{A}$ & A & B \\
\hline Dua hari sekali & $0,80 \mathrm{a}$ & $1,28 \mathrm{a}$ & $0,85 \mathrm{a}$ & $1,16 \mathrm{a}$ \\
\hline & A & B & A & $\mathrm{AB}$ \\
\hline Tiga hari sekali & $0,84 \mathrm{a}$ & $1,11 \mathrm{a}$ & $1,09 \mathrm{a}$ & $0,61 \mathrm{a}$ \\
\hline & A & $\mathrm{AB}$ & A & A \\
\hline
\end{tabular}

BNT 5\%

0,58

$\overline{\text { Keterangan:Bilangan yang didampingi oleh huruf kecil yang sama pada baris yang sama atau huruf }}$ besar yang sama pada kolom yang sama menunjukkan tidak berbeda nyata pada uji BNT taraf $5 \%$, hst $=$ hari setelah tanam, $\mathrm{BNT}=$ Beda Nyata Terkecil

Pada frekuensi pemberian air sehari sekali, bobot kering daun terberat didapatkan pada pemberian air sebanyak $1200 \mathrm{~mm} \mathrm{musim}^{-1}$. Pengurangan jumlah air dari $1200 \mathrm{~mm} \mathrm{musim}^{-1}$ menjadi 300, 600 dan 900 menurunkan bobot kering daun masing-masing sebesar 51,68\%, $62,42 \%$ dan $42,28 \%$. Pemberian air sebanyak 300, 600 dan $900 \mathrm{~mm} \mathrm{musim}^{-1}$ menunjukkan 
bobot kering daun yang tidak berbeda nyata. Bobot kering daun yang ditunjukkan pada frekuensi pemberian air dua hari sekali adalah tidak berbeda nyata pad semua level jumlah pemberian air. Hal yang demikian juga diperlihatkan pada frekuensi tiga hari sekali.

Ketika dilihat dari perlakuan jumlah air terhadap frekuensinya, didapatkan bahwa pada pemberian 300 dan $900 \mathrm{~mm} \mathrm{musim}^{-1}$ bobot kering daun menunjukkan hasil yang tidak berbeda nyata pada semua level frekuensi pemberian air. Pada jumlah pemberian $600 \mathrm{~mm}$ musim $^{-1}$ peningkatan frekuensi pemberian dari sehari sekali menjadi dua hari sekali menunjukkan peningkatan bobot kering daun sebesar 56,25\%. Bobot kering daun memperlihatkan hasil yang tidak berbeda nyata pada frekuensi pemberian sehari sekali dan tiga hari sekali. Di sisi lain, frekuensi pemberian dua hari sekali dan tiga hari sekali juga memperlihatkan bobot kering daun yang tidak berbeda nyata. Pada perlakuan pemberian sebanyak $1200 \mathrm{~mm}$ musim $^{-1}$, pengurangan frekuensi pemberian dari tiga hari sekali menjadi sehari sekali akan meningkatkan bobot kering daun sebesar 59,06\%. Bobot kering yang didapatkan pada tanaman yang diberi air dengan frekuensi sehari sekali dan dua hari sekali menunjukkan hasil yang tidak berbeda nyata. Begitu pula dengan frekuensi dua hari sekali dan tiga hari sekali.

\section{Bobot kering total tanaman}

Rerata luas daun akibat terjadinya interaksi nyata antara jumlah dan frekuensi pemberian air disajikan pada Tabel 5.

Tabel 5. Rerata bobot kering total tanaman akibat interaksi nyata antara jumlah dan frekuensi pemberian air pada umur $27 \mathrm{hst}$

\begin{tabular}{lrrrr}
\hline Frekuensi & \multicolumn{4}{c}{ Jumlah Pemberian Air $\mathbf{( m m}$ musim $\left.^{-1}\right)$} \\
Penyiraman & 300 & 600 & 900 & 1200 \\
\cline { 2 - 5 } & $1,70 \mathrm{ab}$ & $1,40 \mathrm{a}$ & $2,16 \mathrm{ab}$ & $3,04 \mathrm{~b}$ \\
Sehari sekali & $\mathrm{A}$ & $\mathrm{A}$ & $\mathrm{A}$ & $\mathrm{B}$ \\
Dua hari sekali & $1,72 \mathrm{a}$ & $2,68 \mathrm{a}$ & $1,63 \mathrm{a}$ & $2,52 \mathrm{a}$ \\
& $\mathrm{A}$ & $\mathrm{A}$ & $\mathrm{A}$ & $\mathrm{AB}$ \\
Tiga hari sekali & $1,99 \mathrm{a}$ & $2,37 \mathrm{a}$ & $2,20 \mathrm{a}$ & $1,34 \mathrm{a}$ \\
& $\mathrm{A}$ & $\mathrm{A}$ & $\mathrm{A}$ & $\mathrm{A}$ \\
\hline
\end{tabular}

BNT 5\%
$\begin{array}{r}\text { Keterangan: } \\ \text { bilangan yang didampingi oleh huruf kecil yang sama pada baris yang sama atau huruf } \\ \text { besar yang sama pada kolom yang sama menunjukkan tidak berbeda nyata pada uji BNT } \\ \text { taraf } 5 \% \text {, hst }=\text { hari setelah tanam, BNT = Beda Nyata Terkecil }\end{array}$

Pada frekuensi pemberian air sehari sekali, bobot kering total tanaman pada jumlah pemberian 900 dan $1200 \mathrm{~mm} \mathrm{musim}^{-1}$ tidak berbeda nyata. Sedangkan di satu sisi bobot kering total tanaman yang ditunjukkan pada pemberian 300, 600 dan $900 \mathrm{~mm} \mathrm{musim}^{-1}$ juga tidak berbeda nyata. Penurunan sebesar $44,08 \%$ dan $53,95 \%$ terjadi ketika pemberian air dikurangi dari $1200 \mathrm{~mm} \mathrm{musim}^{-1}$ menjadi 300 dan $600 \mathrm{~mm} \mathrm{musim}^{-1}$. Pada frekuensi pemberian dua hari sekali, bobot kering total tanaman menunjukkan hasil yang tidak berbeda nyata pada semua level jumlah pemberian air. Hal yang demikian juga terjadi pada frekuensi pemberian tiga hari sekali.

Bobot kering yang dihasilkan pada pemberian air sebanyak 300 hingga $900 \mathrm{~mm} \mathrm{musim}^{-1}$ tidak berbeda nyata pada semua level frekuensi pemberian air. Akan tetapi, pada pada pemberian air sebanyak $1200 \mathrm{~mm} \mathrm{musim}^{-1}$ dengan frekuensi tiga hari sekali menunjukkan bobot kering total tanaman terendah. Pengurangan frekuensi pemberian air dari tiga hari sekali menjadi sehari sekali dan dua hari sekali akan meningkatkan bobot kering total tanaman sebesar $46,82 \%$ dan $55,92 \%$. Adapun, pemberian air dengan frekuensi sehari dan dua hari memperlihatkan bobot kering total tanaman yang tidak berbeda nyata.

\section{Luas daun, bobot kering daun, bobot kering total tanaman umur 81 hst}

Rerata luas daun per tanaman, bobot kering daun dan bobot kering total tanaman disajikan pada Tabel 6. 
Tabel 6. Rerata luas daun per tanaman $\left(\mathrm{cm}^{2}\right)$, bobot kering daun $\left(\mathrm{g} \mathrm{tan}^{-1}\right)$ dan bobot kering total tanaman $\left(\mathrm{g} \mathrm{tan}^{-1}\right)$ pada berbagai jumlah dan frekuensi pemberian air pada umur 81 hst

\begin{tabular}{|c|c|c|c|}
\hline \multirow[b]{2}{*}{ Perlakuan } & \multicolumn{3}{|c|}{ Umur pengamatan 81 hst } \\
\hline & $\mathrm{LD}\left(\mathrm{cm}^{2}\right)$ & $\begin{array}{c}\text { BK Daun } \\
\left(\mathrm{g} \mathrm{tan}^{-1}\right)\end{array}$ & $\begin{array}{c}\text { BK Total Tanaman } \\
\left(\mathrm{g} \mathrm{tan}^{-1}\right)\end{array}$ \\
\hline \multicolumn{4}{|c|}{ Jumlah air (mm musim $\left.{ }^{-1}\right)$} \\
\hline $300 \mathrm{~mm}$ & $244,29 \mathrm{a}$ & $0,68 \mathrm{a}$ & $2,43 \mathrm{a}$ \\
\hline $600 \mathrm{~mm}$ & $864,70 \mathrm{~b}$ & $2,25 \mathrm{~b}$ & $5,30 \mathrm{a}$ \\
\hline $900 \mathrm{~mm}$ & $1639,73 \mathrm{c}$ & $4,40 \mathrm{c}$ & $10,10 \mathrm{~b}$ \\
\hline $1200 \mathrm{~mm}$ & $1685,78 \mathrm{c}$ & $4,00 \mathrm{c}$ & $11,11 \mathrm{~b}$ \\
\hline BNT 5\% & 520,23 & 1,54 & 3,37 \\
\hline \multicolumn{4}{|c|}{ Frekuensi Pemberian Air } \\
\hline Sehari sekali & 1114,03 & 2,98 & 7,76 \\
\hline Dua hari sekali & 1131,70 & 2,87 & 7,39 \\
\hline Tiga hari sekali & 1080,14 & 2,66 & 6,55 \\
\hline BNT 5\% & tn & tn & $\operatorname{tn}$ \\
\hline
\end{tabular}

Keterangan:Bilangan yang didampingi oleh huruf yang sama pada parameter dan kolom yang sama tidak berbeda nyata pada uji BNT taraf 5\%, hst $=$ hari setelah tanam, tn $=$ tidak nyata, $\mathrm{BNT}=$ Beda Nyata Terkecil

Tabel 6 menunjukkan bahwa luas daun per tanaman paling sempit didapatkan pada

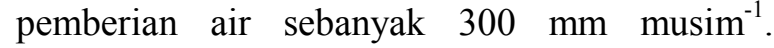
Peningkatan luas daun sebesar $71,75 \%, 85,10 \%$ dan $85,51 \%$ terjadi ketika pemberian air ditambah dari $300 \mathrm{~mm} \mathrm{musim}^{-1}$ menjadi 600,900 dan $1200 \mathrm{~mm} \mathrm{musim}^{-1}$. Peningkatan luas daun sebesar $47,27 \%$ dan $48,71 \%$ juga terjadi ketika jumlah pemberian air ditambah dari $600 \mathrm{~mm}$ musim $^{-1}$ menjadi 900 dan $1200 \mathrm{~mm}$ musim $^{-1}$. Pemberian air sebanyak 900 dan $1200 \mathrm{~mm}$ musim $^{-1}$ tidak berbeda nyata. Pola yang serupa juga menghasilkan bobot kering daun. Pemberian air sebanyak $300 \mathrm{~mm}$ musim $^{-1}$ masih memberikan bobot kering daun paling rendah. Penambahan air dari $300 \mathrm{~mm}^{\text {musim }}{ }^{-1}$ menjadi 600, 900 dan $1200 \mathrm{~mm} \mathrm{musim}^{-1}$ mampu meningkatkan bobot kering daun masing-masing sebesar $69,78 \%, 84,54 \%$ dan $83 \%$. Peningkatan bobot kering daun masing-masing sebanyak $48,86 \%$ dan $43,75 \%$ juga terjadi ketika jumlah air ditambahkan dari $600 \mathrm{~mm} \mathrm{musim}^{-1}$ menjadi 900 dan $1200 \mathrm{~mm} \mathrm{musim}^{-1}$. Hasil bobot kering daun yang diberi air sebanyak 900 dan $1200 \mathrm{~mm}$ musim $^{-1}$ tidak berbeda nyata.

Bobot kering total tanaman yang diberi air sebanyak 300 dan $600 \mathrm{~mm} \mathrm{musim}^{-1}$ tidak berbeda nyata dan lebih rendah jika dibandingkan dengan pemberian air sebanyak 900 dan $1200 \mathrm{~mm}^{\text {musim }}{ }^{-1}$ pada umur 81 hst. Penambahan jumlah air dari $300 \mathrm{~mm} \mathrm{musim}^{-1}$ menjadi 900 dan $1200 \mathrm{~mm}$ musim $^{-1}$ menyebabkan terjadinya peningkatan bobot kering total tanaman sebesar 75,94\% dan $78,13 \%$. Peningkatan sebesar $47,52 \%$ dan $52,29 \%$ juga terjadi ketika jumlah air ditingkatkan dari $600 \mathrm{~mm} \mathrm{musim}^{-1}$ menjadi 900 dan $1200 \mathrm{~mm} \mathrm{musim}^{-1}$. Bobot kering total tanaman memperlihatkan hasil yang tidak berbeda nyata pada pemberian air sebanyak 900 dan $1200 \mathrm{~mm} \mathrm{musim}^{-1}$.

\section{Harga Satuan Daun (HSD) dan Laju Pertumbuhan Relatif (LPR)}

Harga Satuan Daun menggambarkan peningkatan biomassa per unit waktu dan luas daun [9], sedangkan [10] menyatakan Laju Pertumbuhan Relatif sebagai peningkatan berat kering per unit biomassa dan per unit satuan waktu pada kondisi optimal. Rerata Harga Satuan Daun (HSD) dan Laju Petumbuhan Relatif (LPR) pada umur 27 dan 81 hst disajikan pada Tabel 7.

Tabel 7. Rerata Harga Satuan Daun (HSD) dan Laju Pertumbuhan Relatif (LPR) pada berbagai jumlah dan frekuensi pemberian air

\begin{tabular}{cc|c}
\hline Perlakuan & $\begin{array}{c}\text { Harga Satuan Daun } \\
\left(\mathrm{mg} \mathrm{cm}^{-2} \mathrm{hari}^{-1}\right)\end{array}$ & $\begin{array}{c}\text { Laju Pertumbuhan Relatif } \\
(\mathrm{g} \text { g-1 hari-1) }\end{array}$ \\
\hline
\end{tabular}




\begin{tabular}{|c|c|c|c|c|}
\hline & $27 \mathrm{hst}$ & $81 \mathrm{hst}$ & $27 \mathrm{hst}$ & $81 \mathrm{hst}$ \\
\hline \multicolumn{5}{|c|}{ Jumlah air (mm musim $\left.{ }^{-1}\right)$} \\
\hline 300 & $0,05 \mathrm{a}$ & 0,02 & $0,009 \mathrm{a}$ & 0,003 \\
\hline 600 & $0,19 \mathrm{ab}$ & 0,04 & $0,034 \mathrm{~b}$ & 0,006 \\
\hline 900 & $0,29 \mathrm{ab}$ & 0,03 & $0,055 \mathrm{c}$ & 0,005 \\
\hline 1200 & $0,31 \mathrm{~b}$ & 0,08 & $0,053 \mathrm{bc}$ & 0,012 \\
\hline BNT 5\% & 0,25 & tn & 0,020 & tn \\
\hline \multicolumn{5}{|c|}{ Frekuensi Pemberian Air } \\
\hline Dua hari sekali & 0,19 & 0,05 & 0,039 & 0,007 \\
\hline Tiga hari sekali & 0,22 & 0,04 & 0,035 & 0,007 \\
\hline BNT 5\% & tn & $\operatorname{tn}$ & tn & tn \\
\hline
\end{tabular}

Keterangan:Bilangan yang didampingi oleh huruf yang sama pada parameter dan kolom yang sama tidak berbeda nyata pada uji BNT taraf $5 \%$, hst $=$ hari setelah tanam, th = tidak nyata, BNT = Beda Nyata Terkecil

Berdasarkan Tabel 7, perlakuan jumlah air yang diberikan hanya berpengaruh nyata pada 27 hst pada kedua parameter pertumbuhan tanaman yang diamati, sedangkan perlakuan frekuensi pemberian air tidak memberikan pengaruh yang nyata. Pada umur $81 \mathrm{hst}$, kedua perlakuan tidak menunjukkan hasil yang nyata. Jumlah pemberian air 300 hingga $900 \mathrm{~mm} \mathrm{\text {musim } ^ { - 1 }}$ menghasilkan luas daun yang tidak berbeda nyata. Peningkatan jumlah daun sebesar $83,87 \%$ terjadi ketika jumlah pemberian air ditingkatkan dari 300 menjadi $1200 \mathrm{~mm} \mathrm{musim}^{-1}$.

Pada umur 27 hst, LPR yang paling rendah didapatkan pada pemberian air sebesar $300 \mathrm{~mm}$ musim $^{-1}$. Penambahan jumlah air dari $300 \mathrm{~mm}$ musim $^{-1}$ menjadi 600,900 dan $1200 \mathrm{~mm}_{\text {musim }}{ }^{-1}$ juga akan meningkatkan LPR masing-masing sebesar $73,53 \%, 83,64 \%$ dan $83,02 \%$. Hal yang demikian juga terjadi ketika pemberian air ditambahkan dari $600 \mathrm{~mm}^{\text {musim }}{ }^{-1}$ menjadi 900 $\mathrm{mm}$ musim $^{-1}$, yaitu terjadi peningkatan LPR sebesar 38,18\%. LPR memperlihatkan hasil yang tidak nyata pada pemberian air sebanyak 600 dan $1200 \mathrm{~mm} \mathrm{musim}^{-1}$, demikian juga dengan LPR pada pemberian air sejumlah 900 dan $1200 \mathrm{~mm}$ musim $^{-1}$.

\section{Efisiensi Penggunaan Air (EPA)}

Menurut Goldsworthy and Fisher [8], Efisiensi Penggunaan Air menggambarkan jumlah asimilat yang tersimpan per satuan evapotranspirasi. Rerata Efisiensi Penggunaan Air (EPA) akibat terjadinya interaksi nyata antara jumlah dan frekuensi pemberian air disajikan pada Tabel 8.

Tabel 8. Rerata Efisiensi Penggunaan Air (EPA) $\left(\mathrm{g} \mathrm{kg} \mathrm{air}^{-1}\right)$ akibat interaksi nyata antara jumlah dan frekuensi pemberian air

\begin{tabular}{lrrrr}
\hline \multicolumn{1}{c}{ Frekuensi } & \multicolumn{5}{c}{ Jumlah air $\left(\mathbf{m m} \mathbf{~ m u s i m}^{\mathbf{- 1}}\right)$} \\
\cline { 2 - 5 } Pemberian Air & $\mathbf{3 0 0}$ & $\mathbf{6 0 0}$ & $\mathbf{9 0 0}$ & $\mathbf{1 2 0 0}$ \\
\hline Sehari sekali & $0,55 \mathrm{ab}$ & $0,73 \mathrm{bc}$ & $0,82 \mathrm{c}$ & $0,72 \mathrm{bc}$ \\
& $\mathrm{A}$ & $\mathrm{B}$ & $\mathrm{B}$ & $\mathrm{AB}$ \\
Dua hari sekali & $0,65 \mathrm{abc}$ & $0,63 \mathrm{abc}$ & $0,47 \mathrm{ab}$ & $0,87 \mathrm{c}$ \\
& $\mathrm{A}$ & $\mathrm{AB}$ & $\mathrm{A}$ & $\mathrm{B}$ \\
Tiga hari sekali & $0,52 \mathrm{ab}$ & $0,43 \mathrm{a}$ & $0,40 \mathrm{a}$ & $0,53 \mathrm{ab}$ \\
& $\mathrm{A}$ & $\mathrm{A}$ & $\mathrm{A}$ & $\mathrm{A}$ \\
\hline
\end{tabular}

BNT 5\%

0,25

Keterangan:Bilangan yang didampingi oleh huruf kecil yang sama pada baris yang sama atau huruf besar yang sama pada kolom yang sama menunjukkan tidak berbeda nyata pada uji BNT taraf $5 \%$, hst $=$ hari setelah tanam, BNT $=$ Beda Nyata Terkecil

Pada frekuensi pemberian air sehari sekali, EPA dari pemberian air sebanyak 300, 600 dan $1200 \mathrm{~mm} \mathrm{musim}^{-1}$ menunjukkan hasil yang tidak berbeda nyata. Penambahan jumlah air dari 300 $\mathrm{mm}$ musim $^{-1}$ menjadi $900 \mathrm{~mm}$ musim $^{-1}$ meningkatkan EPA sebesar 32,93\%. EPA yang 
tidak nyata juga diperlihatkan pada pemberian air 600, 900 dan $1200 \mathrm{~mm}^{\text {musim }}{ }^{-1}$. Sedangkan pada frekuensi pemberian air dua hari sekali, peningkatan EPA sebesar 45,98\% terjadi ketika jumlah pemberian air ditambah dari $900 \mathrm{~mm}$ musim $^{-1}$ menjadi $1200 \mathrm{~mm}$ musim $^{-1}$. EPA menunjukkan hasil yang tidak berbeda nyata pada frekuensi pemberian air tiga hari sekali pada semua level jumlah pemberian air.

Adapun EPA yang didapatkan pada pemberian air sebanyak 300, 600 dan $900 \mathrm{~mm}$ musim $^{-1}$ memperlihatkan hasil yang tidak berbeda nyata. Demikian juga EPA yang didapatkan pada pemberian air sebanyak 300, 600 dan $1200 \mathrm{~mm} \mathrm{musim}^{-1}$ yang menunjukkan perbedaan yang tidak nyata. Pada pemberian air dengan frekuensi tiga hari sekali EPA memperlihatkan hasil yang tidak berbeda nyata pada semua level jumlah pemberian air.

Apabila dilihat dari jumlah pemberian air terhadap frekuensinya, pemberian air sebanyak $300 \mathrm{~mm} \mathrm{musim}^{-1}$ menunjukkan EPA yang tidak berbeda nyata pada semua level frekuensi pemberian air. Pada pemberian air sebanyak 600 $\mathrm{mm}$ musim $^{-1}$ peningkatan frekuensi pemberian air dari sehari sekali menjadi tiga hari sekali akan menurunkan EPA sebesar 41,1\%. EPA yang didapatkan pada frekuensi pemberian air sehari sekali dan dua hari sekali menunjukkan hasil yang tidak berbeda nyata, demikian juga dengan EPA pada frekuensi pemberian air dua hari sekali dan tiga hari sekali. Sedangkan pada pemberian air sebanyak $900 \mathrm{~mm}$ musim $^{-1}$ EPA menurun sebesar $51,22 \%$ ketika frekuensi pemberian air ditingkatkan dari sehari sekali menjadi tiga hari sekali. EPA yang tidak berbeda nyata diperlihatkan pada pemberian air sehari sekali dan dua hari sekali, demikian pula EPA yang didapatkan pada pemberian air dua hari sekali dan tiga hari sekali. Pada pemberian air sebanyak $1200 \mathrm{~mm} \mathrm{musim}^{-1}$, EPA meningkat $39,08 \%$ ketika pemberian air ditingkatkan dari dua hari sekali menjadi tiga hari sekali. EPA memperlihatkan hasil yang tidak berbeda nyata pada pemberian air sehari sekali dan dua hari sekali, maupun pemberian air sehari sekali dan tiga hari sekali.

\section{Komponen Hasil}

Rerata jumlah umbi, bobot basah dan kering umbi disajikan pada Tabel 9.

Tabel 9. Jumlah umbi per tanaman, bobot basah umbi per tanaman (g) dan bobot kering umbi per tanaman (g) saat panen pada berbagai jumlah dan frekuensi pemberian air

\begin{tabular}{lccc}
\hline Perlakuan & $\sum$ umbi & BB Umbi & BK Umbi \\
\hline${\left.\text { Jumlah air (mm } \text { musim }^{-1}\right)}$ & & \\
300 & 0,44 & 0,24 & 0,02 \\
600 & 1,00 & 0,82 & 0,09 \\
900 & 0,78 & 1,19 & 0,11 \\
1200 & 1,11 & 3,35 & 0,28 \\
\hline \multicolumn{1}{c}{ BNT 5\% } & tn & tn & tn \\
\hline
\end{tabular}

\begin{tabular}{lccc} 
Frekuensi Pemberian Air & & & \\
Sehari sekali & 1,25 & 1,62 & 0,17 \\
Dua hari sekali & 0,75 & 2,37 & 0,18 \\
Tiga hari sekali & 0,50 & 0,21 & 0,03 \\
\hline \multicolumn{1}{c}{ BNT 5\% } & tn & tn & tn \\
\hline
\end{tabular}

Keterangan:Bilangan yang didampingi oleh huruf yang sama pada parameter dan kolom yang sama tidak berbeda nyata pada uji BNT taraf $5 \%$, hst $=$ hari setelah tanam, $\mathrm{tn}=$ tidak nyata, BNT $=$ Beda Nyata Terkecil, $\sum$ umbi $=$ jumlah umbi, $\mathrm{BB}$ umbi $=$ bobot basah umbi, $\mathrm{BK}$ umbi $=$ bobot kering umbi

\section{PEMBAHASAN}

Sebagai salah satu unsur penting yang dibutuhkan oleh tanaman dalam pertumbuhan dan perkembangannya, banyak sedikitnya air yang tersedia harus memenuhi kebutuhan tersebut. Selain karena dalam tanaman itu sendiri terdiri dari $80-90 \%$ air di dalam vakuola, air juga memiliki fungsi penting bagi tanaman yaitu sebagai zat pengangkut unsur-unsur hara dari tanah dan udara ke seluruh tubuh tanaman, pengatur suhu tanaman melalui proses evaporasi, sebagai media untuk beberapa proses biosintesis, sebagai reaktan dalam proses fotosintesis dan berpengaruh pada proses perpanjangan dan pertumbuhan sel. Oleh karena pentingnya peran 
air tersebut bagi tanaman, maka air menjadi faktor pembatas dalam menentukan tingkat keberhasilan tanaman. Banyak sedikitnya air yang tersedia di lingkungan sekitar tanaman akan memberikan pengaruh pada pertumbuhan dan produksi tanaman.

Hasil penelitian menunjukkan bahwa terjadi interaksi antara jumlah dan frekuensi pemberian air pada beberapa komponen pertumbuhan tanaman kentang hitam, yaitu pada komponen jumlah daun pada umur 54 dan 81 hst, luas daun pada umur 27 hst, bobot kering daun pada umur 27 hst, serta bobot segar dan kering total tanaman pada umur 27 dan 131 hst. Pada komponen analisis pertumbuhan tanaman, interaksi nyata terjadi pada parameter Efisiensi Pemberian Air, sedangkan pada komponen lingkungan mikro, interaksi nyata terjadi pada parameter $\mathrm{pH}$ pada umur $131 \mathrm{hst}$. Jumlah air juga memberikan pengaruh nyata pada beberapa komponen pertumbuhan yang diamati, meliputi panjang akar, bobot kering akar, jumlah daun, luas daun, bobot kering daun, bobot kering batang, serta pada beberapa komponen hasil, yaitu bobot segar dan bobot kering total tanaman. Sedangkan frekuensi pemberian air pada umumnya tidak memberikan pengaruh yang nyata pada semua komponen pertumbuhan dan hasil, analisis pertumbuhan tanaman serta lingkungan mikro, kecuali pada $\mathrm{pH}$ tanah pada umur 54 hst.

Interaksi tidak terjadi di sepanjang umur pengamatan. Hal ini dikarenakan pemberian air dilakukan dengan berpatokan pada koefisien tanaman $(\mathrm{Kc})$. Koefisien tanaman (Kc) mampu menggambarkan laju kehilangan air yang berbanding dengan banyaknya energi yang digunakan oleh tanaman untuk tumbuh pada setiap fase pertumbuhannya. Kehilangan air dan jumlah energi yang dibutuhkan dalam proses pertumbuhan pada tiap fase berbeda-beda sehingga mengakibatkan nilai koefisien tanaman yang berbeda pula. Dalam penelitian ini, jumlah air yang diberikan juga disesuaikan dengan besarnya koefisien tanaman pada masing-masing fase sehingga pada beberapa fase, terutama fasefase akhir pertumbuhan, banyaknya air yang diberikan dalam satu waktu mampu mencukupi kebutuhan air tanaman tersebut. Hal ini akan mempengaruhi banyaknya air tersedia di sekitar tanaman dan penambahan pemberian air akan memicu terjadinya kondisi water logging atau penggenangan, sehingga perlakuan frekuensi pemberian air menjadi tidak memberikan pengaruh yang nyata.
Interaksi antara jumlah dan frekuensi pemberian air pada luas daun, bobot kering daun, bobot segar dan kering total tanaman pada umur 27 hst menunjukkan bahwa tanaman yang diberi air sebanyak $1200 \mathrm{~mm}^{\text {musim }}{ }^{-1}$ yang diberikan sehari sekali ataupun dua hari sekali memberikan hasil yang paling berat dibandingkan perlakuan jumlah air yang lain pada umur pengamatan yang sama. Hal ini mengindikasikan bahwa pemberian air sebanyak $1200 \mathrm{~mm} \mathrm{musim}^{-1}$ yang diberikan sehari sekali dan dua hari sekali mampu memenuhi kebutuhan air untuk pertumbuhan dan perkembangan organ-organ tanaman pada 27 hari pertama. Sitompul dan Guritno [9] menjelaskan bahwa, awal pertumbuhan tanaman bergantung pada substrat yang ada di dalam bahan tanam yang digunakan, yang kemudian akan mengalami perombakan secara enzimatis. Substrat tersebut bisa berupa karbohidrat, lemak dan protein. Setelah substrat awal habis, luas daun dan efisiensi tanaman dalam fiksasi $\mathrm{CO}_{2}$ akan mempengaruhi ketersediaan substrat tanaman dalam membentuk biomassa yang nantinya akan digunakan tanaman dalam pemeliharaan fungsi organ, dikonversikan ke dalam struktur tanaman dan sisanya akan disimpan sebagai bahan cadangan. Proses tersebut tidaklah lepas dari peran air sebagai salah satu bahan utama dalam proses fotosintesis dan biomassa tanaman akan diperoleh dari proses tersebut. Pemberian air sebanyak $1200 \mathrm{~mm}$ musim $^{-1}$ yang diberikan sehari sekali dan dua hari sekali dapat menunjang kelancaran proses fotosintesis tanaman. Oleh karena daun ialah organ utama dalam proses tersebut, biomassa yang dihasilkan akan ditranslokasikan untuk pembentukan daun baru dan pemeliharaan daun yang aktif daripada pembentukan organ tanaman yang lain.

Pemberian air sebanyak 900 hingga $1200 \mathrm{~mm}$ musim $^{-1}$ pada umumnya memberikan hasil yang lebih tinggi pada komponen pertumbuhan yang diamati, terutama pada kompenen bobot kering akar, jumlah dan luas daun, serta bobot kering daun dan batang, dibandingkan pemberian air sebanyak 300 dan $600 \mathrm{~mm}$ musim $^{-1}$. Hasil terendah didapatkan pada tanaman yang diberi air sebanyak $300 \mathrm{~mm}$ musim $^{-1}$ yang menunjukkan bahwa jumlah tersebut belum mencukupi kebutuhan air dalam pertumbuhan tanaman kentang hitam sehingga tanaman akan mengalami stres. Hubungan antara jumlah pemberian air dan bobot kering total tanaman dinyatakan dengan persamaan $y=0,0013 x+1,1211 \quad\left(R^{2}=0,9184\right) . \quad$ Berdasarkan 
persamaan tersebut maka setiap penambahan jumlah air sebanyak $1 \mathrm{~mm}$ musim $^{-1}$ akan meningkatkan bobot kering total tanaman sebesar 0,0013 $\mathrm{g} \mathrm{tan}^{-1}$ (Gambar 1). Akan tetapi, bobot kering total tanaman akan berkurang sebesar $0,2283 \mathrm{~g} \tan ^{-1}$ ketika dilakukan penundaan penyiraman per harinya. Hal tersebut dinyatakan dengan persamaan $\mathrm{y}=$ $0,2283 \mathrm{x}+2,5186 \quad\left(\mathrm{R}^{2}=0,6529\right) \quad($ Gambar 1$)$. Slatyer [11] menjelaskan bahwa defisit air akan menyebabkan proses fisiologis tanaman terganggu karena terhambatnya inisiasi dan

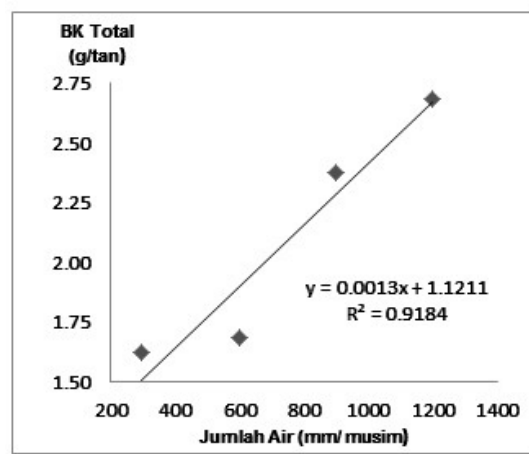

deferensiasi meristem apikal. Perkembangan akar, batang dan perluasan daun juga akan terpengaruh akibat pembagian dan pembesaran sel yang terhambat. Selain itu, akibat dari perluasan daun yang tidak optimal, maka proses fotosintesis akan berkurang dan akan mempengaruhi laju pertumbuhan tanaman. Penutupan stomata sebagai akibat dari adaptasi tanaman untuk mengawetkan air dalam kondisi defisit air juga menjadi salah satu faktor yang mempengaruhi laju fotosintesis.

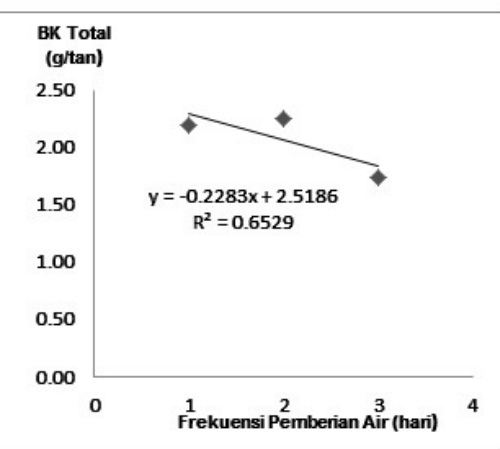

Gambar 1. Hubungan bobot kering total tanaman akibat pengaruh jumlah (kiri) dan frekuensi pemberian air (kanan)

Sebaliknya, meskipun komponen pertumbuhan dari tanaman yang diberi air sebanyak 900 hingga $1200 \mathrm{~mm}$ musim $^{-1}$ memberikan hasil yang lebih tinggi jika dibandingkan dengan jumlah air yang lain, akan tetapi kondisi tersebut juga tidak dapat dikatakan sebagai kondisi yang normal. Hal ini ditandai dengan beberapa perubahan morfologi tanaman, terutama pada bagian pangkal batang yang kontak langsung dengan tanah. Suatu perubahan morfologi ini ialah terbentuknya hipertrofi lentisel, sebagai hasil dari pembengkakan jaringan yang terdapat di dasar batang sebagai akibat dari pembelahan dan pembesaran sel radial yang berkaitan dengan keberadaan hormon etilen dan auksin (IAA). Parent et al. [12] menyatakan bahwa terbentuknya hipertrofi lentisel ini dalam rangka memfasilitasi difusi $\mathrm{O}_{2}$ menuju akar dan sebagai ventilasi potensial produk samping metabolisme anaerob seperti $\mathrm{CO} 2, \mathrm{CH} 4$ dan etanol, yang diproduksi di akar. Groh et al. (2002) juga berpendapat bahwa perkembangan lebih lanjut hipertrofi lentisel ini akan dapat mengembalikan konduktansi stomata ke tingkat yang lebih mudah dikontrol oleh tanaman.

Perubahan morfologi yang lain ialah terbentuknya akar adventif sebagai pengganti akar utama, karena akar utama tidak lagi mampu memasok air akibat kondisi tanah yang jenuh air. Hal tersebut sekaligus dalam rangka mengefisiensikan penggunaan energi untuk memproduksi akar yang lebih sesuai untuk menunjang kebutuhan air dan mineral untuk tanaman. Terbentuknya akar adventif ini akan menggantikan sistem akar yang normal karena letaknya yang ada di perbatasan tanah dengan kondisi jenuh air dan atmosfir. Hal tersebut juga mencerminkan tingginya tingkat toleransi tanaman terhadap genangan. Sejalan dengan perkembangannya, kehadiran akar tersebut akan dikaitkan dengan produksi etilen. Berdasarkan hal tersebut dapat diindikasikan bahwa tanaman kentang hitam sebenarnya memiliki toleransi terhadap kondisi jenuh air dengan membentuk bagian tambahan tersebut. Akan tetapi pada perkembangan tanaman selanjutnya hal ini tidak menguntungkan, terutama dalam fase pembentukan umbi sebagai lokasi penimbunan asimilat pada tanaman umbi-umbian.

Pada komponen hasil, jumlah dan frekuensi pemberian air tidak memberikan pengaruh nyata terhadap jumlah umbi, bobot segar dan kering umbi. Hal ini disebabkan karena pada fase inisiasi umbi yang seharusnya dimulai pada \pm 69 hst, tanaman sudah mengalami stres, baik karena kekurangan maupun kelebihan air. Pada tanaman yang diberi air sebanyak $300 \mathrm{~mm} \mathrm{musim}{ }^{-1}$, 
tanaman mengalami stres defisit air yang ditandai dengan morfologi tanaman yang umumnya lebih kecil dibandingkan dengan tanaman yang diberi air dengan jumlah lebih banyak. Akar yang dihasilkan cenderung lebih pendek, sehingga bobot kering akar yang dihasilkan juga kecil. Hal ini akan berpengaruh pada tingkat penyerap-an air oleh tanaman, yang akan menyebabkan pertumbuhan tanaman terganggu. Jumlah daun, luas daun dan bobot kering batang serta bobot kering daun yang menunjukkan hasil yang paling rendah apabila dibandingkan dengan perlakuan pemberian air lainnya, adalah hasil dari berkurangnya fotosintesis dan asupan karbon akibat luas daun yang sempit.

Pembentukan umbi terhambat akibat menurunnya aktivitas metabolisme dan fotosintesis sebagai akibat dari stres kelebihan air. Seperti yang diketahui sebelumnya, umbi adalah bagian pengguna (sink) terbesar untuk menyimpan pati dan alokasi asimilat dari daun atau sumber (source) dan air ialah suatu faktor yang mempengaruhi laju fotosintesis, karena pertumbuhan dan perkembangan umbi sangat tergantung pada efisiensi fotosintesis. Pada kondisi jenuh air, tanaman akan mengalami kekurangan $\mathrm{O}_{2}$ pada tanah yang akan mempengaruhi pertumbuhan dan perkembangan tanaman. Metabolisme respirasi aerob akan beralih kepada respirasi fermentasi anaerob. Parent et al. [12] menjelaskan bahwa ketika respirasi menurun, aliran elektron melalui jalur respirasi akan berkurang sehingga mengurangi produksi ATP yang akan mengakibatkan bahan kimia pengoksidasi (NAD atau nicotinamide adenine dinukleotida) harus dihasilkan melalui jalur yang tidak menggunakan $\mathrm{O}_{2}$ sebagai akseptor elektron terminal. Ketika ADP terbatas, maka tanaman akan mengubah metabolismenya dari respirasi aerob menjadi anaerob yang mencakup dua tahap, yaitu karboksilasi piruvat menjadi asetaldehida dan reduksi asetaldehida menjadi etanol, yang bersamaan dengan proses oksidasi $\mathrm{NAD}(\mathrm{P}) \mathrm{H}$ menjadi $\mathrm{NAD}(\mathrm{P})$. Ketika respirasi aerob mampu menghasilan 36 mol ATP per mol glukosa, jalur metabolisme anaerob hanya mampu mensintesis 2 mol ATP saja. Untuk mengimbangi defisit energi yang terjadi, glikolisis dipercepat, menyebabkan menipisnya cadangan karbohidrat.

Penyebab lainnya ialah terjadi pembusukan akar utama pada tanaman yang mengalami stres kelebihan air. Pembusukan akar utama karena kondisi tanah yang jenuh air akan menyebabkan terbentuknya akar adventif, dimana hal tersebut akan memerlukan energi yang cukup agar tanaman dapat terus bertahan hidup. Di sisi lain, akibat dari pembentukan akar adventif, fase vegetatif tanaman akan menjadi lebih panjang karena daun-daun lama akan mengalami senescense dan daun baru akan terbentuk, seperti yang diungkapkan oleh Araki et al. [13]. Cadangan karbohidrat yang ada akan digunakan dalam proses vegetatif dan ketika tanaman sudah melakukan pemulihan, daun-daun baru tersebut akan menjadi sumber yang baru. Hal ini ditunjukkan pada beberapa umbi yang ditemukan pada saat panen atau sekitar 131 hst, yang tampak memasuki fase pengisian umbi.

Pembentukan umbi juga berkaitan dengan hormon pertumbuhan. Umbi terbentuk akibat adanya pembengkakan bagian sub-apikal pada ujung geragih. Dalam proses pembentukan umbi, hal yang mula-mula terjadi adalah pada umbi yang sangat muda, pembentukan umbi pada ujung geragih diawali dengan perubahan pola pembesaran sel dalam inti sel, yaitu menjadi lebih pendek dan luas, tetapi volumenya meningkat. Sebagai akibat dari perubahan ini, pertumbuhan geragih tersebut menjadi terhambat dan perluasan umbi lateral mulai terjadi. Pada ujung geragih, dinding sel baru akan terbentuk ke arah yang tepat pada sumbu longitudinal, tetapi pada inisiasi selanjutnya akan terjadi kehilangan polaritas akibat perubahan pembelahan sel [19]. Ekspansi sel yang terpolarisasi pada sel tanaman dikendalikan oleh mikrotubulus kortikal yang terletak di bawah membran plasma. Orietasi mikrotubulus ini diatur oleh GA (hormon giberelin) dengan cara mendistribusikan mikrotubulus secara tegak lurus menuju titik tumbuh sel, sehingga mengarah pada perpanjangan sel yang bersamaan dengan perkembangan titik tumbuh. Inisiasi umbi disinyalir akibat pembentukan karbohidrat terlarut dalam jumlah besar pada ujung geragih dan terjadi pada saat kondisi lingkungan yang menekan pertumbuhan batang, seperti fotoperiodik hari pendek atau suhu yang rendah. Akan tetapi, apabila aktivitas GA meningkat akibat suhu yang tinggi atau peningkatan nitrat, maka pembentukan umbi juga akan terhambat. Penelitian yang dilakukan oleh [13] menunjukkan bahwa pemberian GA pada tanaman kentang mampu meningkatkan pertumbuhan batang dan geragih tetapi inisiasi umbi tertunda. Penundaan tersebut tidak berhubungan dengan konsentrasi karbohidrat pada geragih, akan tetapi terkait dengan banyaknya kandungan gula dan pati pada ujung 
geragih akibat suhu yang rendah di awal pembentukan umbi [13]. Pemberian GA akan menunda penumpukan pati dalam umbi.

Inisiasi umbi juga dipengaruhi oleh banyaknya karbohidrat yang dibentuk dalam proses fotosintesis. Karbohidrat yang terbentuk tersebut akan digunakan untuk membentuk akar, batang dan daun, sedangkan kelebihan karbohidrat yang ada dalam bentuk sukrosa akan ditranslokasikan ke ujung geragih, tempat di mana inisiasi umbi akan dimulai. Umbi akan muncul pertama kali pada geragih yang paling ujung dan paling tua. Sukrosa yang sudah banyak menumpuk akan mulai mengisi bagian tersebut. Selama inisiasi umbi, area di belakang ujung geragih akan mengalami pembagian sel, sehingga banyak tunas ketiak atau tunas aksilaris menjadi mata tunas. Sukrosa tersebut akan berubah menjadi pati yang akan disimpan dalam sel umbi sebelum inisiasi umbi nampak [18].

Harga Satuan Daun (HSD) dan Laju Pertumbuhan Relatif (LPR) pada fase awal pertumbuhan dipengaruhi oleh jumlah air, begitu juga dengan Efisiensi Pemberian Air (EPA), tetapi hal tersebut tidak berpengaruh pada fasefase perkembangan selanjutnya hingga menjelang panen. Sementara frekuensi pemberian air umumnya tidak memberikan pengaruh pada HSD, LPR dan EPA, kecuali pada fase-fase awal pertumbuhan. Pemberian air sebanyak 900 hingga $1200 \mathrm{~mm}$ musim $^{-1}$ memberikan nilai HSD dan LPR yang lebih tinggi dibandingkan nilai HSD dan LPR pada tanaman yang diberi air 300 dan $600 \mathrm{~mm} \mathrm{musim}^{-}$ ${ }^{1}$ pada umur 27-54 hst, dan kemudian pada umur 54-81 hst nilai HSD tertinggi didapatkan pada tanaman yang diberi air sebanyak $1200 \mathrm{~mm}$ musim $^{-1}$. Dari hasil HSD tersebut dapat diketahui bahwa jumlah air yang dibutuhkan tanaman untuk melakukan fotosintesis pada fase-fase pembentukan daun hingga fase vegetatif akhir adalah cukup, sehingga mampu menghasilkan biomassa yang dibutuhkan oleh tanaman untuk tumbuh dan berkembang. HSD digambarkan sebagai ke-mampuan suatu daun sebagai organ utama dalam proses fotosintesis dalam menghasilkan biomassa. Tanaman juga tidak mampu memproduksi biomassa yang cukup untuk metabolisme apabila jumlah air kurang dari $900 \mathrm{~mm} \mathrm{musim}^{-1}$, sehingga tanaman akan mengalami stres akibat defisit air. Sitompul dan Guritno [9] menjelaskan bahwa laju fotosintesis akan berubah sesuai dengan umur tanaman dimana laju fotosintesis akan meningkat hingga umur tanaman tertentu dan akan menurun pada umur tanaman selanjutnya yang disebut sebagai arus ontogeni. Hal ini juga menjelaskan mengapa pada fase-fase perkembangan ta-naman mulai memasuki fase inisiasi umbi hingga panen, jumlah air tidak lagi berpengaruh nyata terhadap HSD. Nilai Laju Pertumbuhan Relatif (LPR) menunjukkan bahwa pemberian air sebanyak 900 hingga $1200 \mathrm{~mm}$ musim $^{-1}$ pada awal pertumbuhan tanaman mampu meningkatkan bobot kering yang dihasilkan tanaman per unit biomassa per satuan waktu secara efisien. Sitompul dan Guritno [9] berpendapat bahwa nilai LPR berhubungan dengan HSD, yaitu nilai HSD yang besar akan menghasilkan LPR yang tinggi pula. Hal ini disebabkan adanya hubungan antara pertambahan bobot kering tanaman dengan kemampuan tanaman dalam melakukan fotosintesis. Sehingga dari hasil penelitian, jelas terlihat bahwa LPR berbanding lurus dengan HSD, dimana semakin meningkat HSD maka LPR juga akan meningkat.

Berdasarkan hasil penelitian, Efisiensi Penggunaan Air (EPA) yang menunjukkan jumlah asimilat yang tersimpan per satuan evapotranspirasi [8] dari tanaman yang diberi air sebanyak 600 dan $900 \mathrm{~mm} \mathrm{musim}^{-1}$ jauh lebih besar dibandingkan jumlah asimilat tersimpan dari tanaman yang beri air sebanyak 300 dan $1200 \mathrm{~mm} \mathrm{musim}^{-1}$. Sehingga, dari situ bisa didapatkan bahwa pemberian air sebanyak 600 dan $900 \mathrm{~mm}_{\text {musim }}{ }^{-1}$ lebih ekonomis dan efisien dibandingkan pemberian air yang lebih atau kurang dari jumlah tersebut.

\section{KESIMPULAN}

Terjadi interaksi antara perlakuan jumlah dan frekuensi pemberian air pada pertumbuhan tanaman kentang hitam. Perlakuan pemberian air sebanyak $900 \mathrm{~mm} \mathrm{musim}^{-1}$ pada frekuensi sehari menunjukkan jumlah daun pada umur 54 dan 81 hst, luas daun pada umur 27 hst, bobot kering daun pada umur $27 \mathrm{hst}$, serta bobot segar dan kering total tanaman pada umur 27 dan $131 \mathrm{hst}$ yang lebih tinggi dibandingkan kombinasi perlakuan yang lain. Pada komponen analisis pertumbuhan tanaman, hal yang serupa juga terjadi pada parameter Efisiensi Pemberian Air. Perlakuan jumlah pemberian air menunjukkan bahwa pemberian air sebanyak $900 \mathrm{~mm} \mathrm{musim}^{-1}$ memberikan luas daun, bobot kering daun, bobot kering total tanaman, LPR, bobot kering batang, kelembaban tanah pagi dan siang yang lebih tinggi dibandingkan jumlah pemberian air yang lain. Belum didapatkan informasi tentang 
frekuensi pemberian air yang tepat pada tanaman kentang hitam.

\section{DAFTAR PUSTAKA}

[1] Rajmohan, K., K.V. Peter (ed). 2007. Underutilized and Underexploited Horticultural Crops Vol. I. New India Publishing Agency. New Delhi. India. p. 29-36

[2] Enyiukwu, D. N., A.N Awurum and J.A Nwaneri. 2014. Potentials of Hausa Potato (Solenostemon rotundifolius (Poir.) J. K. Morton) and Management of its Tuber Rot in Nigeria. Greener J. of Agronom. Forest. and Hor. 2(2): 027-037

[3] Nugraheni, M., U. Santoso, Suparmo, H. Wuryastuti. 2011. Potential of Coleus tuberosus as an antioxidant and cancer chemoprevention agent. Int. Food Res. J. 18(4): $1471-1480$

[4] Anbuselvi, S. and M.H. Priya. 2013. Nutritional and anti-nutritional constituents of Plectranthus rotundifolius. Int. J. Pharm. Sci. Rev. Res., 22(1), SepOct 2013

[5] Rajapaksha, U. 1998. Traditional Food Plants in Sri Lanka In Hector Kobbakaduwa Agrarian Research and Training Institute. Sri Lanka, Publication \#100. Sri Lanka. p. 271-273

[6] Bayorbor, T.B., A.Y. Gumah. 2007. Effect of 'seed' tuber weight and spacing on Frafra Potato (Solenostemon rotundifolius). Ghana J. of Horticulture 6: 41-48

[7] Gardner, F.P., R.L Mitchell, R.B. Pearce. 1991. Crop-Physiology; Field CropPhysiology. H. Susilo (penerjemah). 1991. Fisiologi Tanaman Budidaya. UI Press. Jakarta.

[8] Goldsworthy, P.R., N.M. Fisher. 1996. The Physiology of Tropical Field Crops. John Wiley and Sons, Ltd. Tohari (penerjemah), Soedharoedjian (penyunting). Fisiologi Tanaman Budidaya Tropik. Gadjah Mada University Press. Yogyakarta. p. 51-280

[9] Sitompul, S.M dan B. Guritno. 2016. Analisis Pertumbuhan Tanaman. Gadjah Mada University Press, Yogyakarta. p. 81124

[10] Poorter, H. and C. Remkes. 1990. Leaf area ratio and net assimilation rate of 24 wild species differing in relative growth rate. Oecologia 83: 553-559
[11] Slatyer, R.O. 1969. Physiological Significance of Internal Water Relations to Crop Yield in R.C Dinauer (man. ed.), J.D Eastin (ed.), F.A Haskins (ed.), C.Y Sullivan (ed.), C.H.M Van Bavel (ed.). Physiological Aspects of Crop Yield. American Society of Agronomy. Madison. Wis. USA. p. 53-85

[12] Parent, C., N. Capelli, A. Berger, M. Crèvecoeur, J.F. Dat. 2008. An overview of plant responses to soil waterlogging. Plant Stress 2 (1): 20-27

[13] Araki H., Hamada, A., Hossain, M.A., Takahashi, T. 2012. Waterlogging at jointing and/or after anthesis in wheat induces early leaf senescence and impairs grain filling. Field Crops Res. 137: 27-36 